\title{
Risk Factors Associated with Breast Cancer among Women in Addis Ababa, Ethiopia: Unmatched Case-Control Study
}

This article was published in the following Dove Press journal: International Journal of Women's Health

\author{
Lidia Tolessa' \\ Endalew Gemechu Sendo iD ${ }^{2}$ \\ Negalign Getahun Dinegde (iD ${ }^{2}$ \\ Assefa Desalew (iD) \\ 'School of Nursing and Midwifery, \\ College of Health and Medical Sciences, \\ Haramaya University, Harar, Ethiopia; \\ ${ }^{2}$ Department of Nursing and Midwifery, \\ College of Health Science, Addis Ababa \\ University, Addis Ababa, Ethiopia
}

Background: Breast cancer is a common public health problem and the main cause of cancer-related death worldwide. There is a paucity of evidence on the risk factors of breast cancer in Ethiopia. Therefore, we aimed to identify the risk factors of breast cancer among women in Addis Ababa, Ethiopia.

Methods: We conducted an institutional-based unmatched case-control study with a sample of 348 women (116 cases and 232 controls). Participants were selected by a systematic random sampling technique. Data were collected using an interviewer-administered questionnaire. Data were entered using EpiData version 4.6 and analyzed using SPSS version 25. Multivariable analysis was carried out using the adjusted odds ratio (AOR) with a 95\% confidence interval (CI). P-value of less than 0.05 was considered statistically significant.

Results: The mean age (+SD) of the participants was $42.7( \pm 11.3)$ and $40.7( \pm 14.6)$ for the cases and controls, respectively. Early onset of menarche (AOR=4.10; 95\% CI: 1.84, 9.15), rural women $(\mathrm{AOR}=3.64 ; 95 \% \mathrm{CI}: 1.38,9.57)$, utilization of packed foods or drinks $(\mathrm{AOR}=$ 2.80; 95\% CI:1.52, 5.15), and smoke-dried meat (AOR=2.41; 95\% CI:1.36, 4.27), family history of cancer $(\mathrm{AOR}=2.11 ; 95 \% \mathrm{CI}: 1.04,4.26)$, overweight and/or obesity $(\mathrm{AOR}=2.38$; 95\% CI:1.31, 4.31), and women with one or less children $(\mathrm{AOR}=1.86 ; 95 \% \mathrm{CI}: 1.01,3.41)$ were associated factors with breast cancer risk.

Conclusion: In this study, early onset of menarche, rural women, utilization of packed foods or drinks and smoke-dried meat, family history of cancer, overweight and/or obesity, and women with one or fewer children were factors that increased breast cancer risk. Therefore, focusing on modifiable risk factors and increasing awareness of the community such as a healthy diet, promotion of breast self-examination, and creation of programs to increase women's knowledge is important to reduce the increasing burden of breast cancer.

Keywords: breast cancer, risk factors, women, Ethiopia

\section{Background}

Breast cancer is the most common public health problem and the main cause of cancer-related death worldwide. ${ }^{1-4}$ Breast cancer is a type of cancer characterized by uncontrolled development and the spread of abnormal breast cells. ${ }^{5,6}$ Globally, approximately 2.1 million women, which account for $24.2 \%$ of new cancer cases and $627,000(15 \%)$ deaths in 2018. ${ }^{1,7}$ More than half of the incidence of breast cancer and $60 \%$ of deaths occur in low- and middle-income countries (LMICs). ${ }^{1,8}$ For example, African countries had the highest age-standardized mortality rate (17.3 deaths per 100,000 annually) associated with breast cancer., ${ }^{9,10}$
Correspondence: Assefa Desalew

College of Health and Medical Sciences,

Haramaya University, P.O. Box: 235

Harar, Ethiopia

Tel +251913083613

Email assefadI00@gmail.com
International Journal of Women's Health 202I:13 I0I-II0 
In Ethiopia, breast cancer incidence is rising and become the foremost common cancer, causing high rates of morbidity and mortality. ${ }^{11}$ The incidence of breast cancer accounts for 15,244 (22.6\%) all cases of cancer and 8,159 (17\%) cancer mortality annually. ${ }^{7,12}$ The agestandardized incidence rate of breast cancer was 40.6 per 100,000 females. ${ }^{11}$ According to the Addis Ababa cancer registry, breast cancer incidence increased from 18 to 160 new cases between 2012 and 2018 in Addis Ababa. ${ }^{13}$

Although breast cancer overwhelmingly occurs in high-income countries, recently, the burden has extended in LMICs due to factors such as a westernized lifestyle and urbanization. ${ }^{1-4}$ Evidence indicates that breast cancer has several influences, including psychological distress to the patients, family members, reduced productivity, and increased cost of the health care system. ${ }^{14-17}$ In African countries, including Ethiopia, the health care system cannot handle care and treatment for the expanding incidence rates of breast cancer due to inappropriate treatment strategies in place and economic barriers. Therefore, focusing on preventive strategies through appropriate identification and exposure reduction to established risk factors is important. $^{10,18}$

According to the World Health Organization (WHO) and American Cancer society, they recognized several risk factors for breast cancer, including early menarche, late menopause, null parity, late age at first pregnancy $(>30$ years), non-breastfeeding mothers, hormonal contraceptives, hormone therapy after menopause, alcohol, cigarette smoking, obesity, physical inactivity, diet, and family history of breast cancer. ${ }^{6,19-21}$ Several risk factors are assumed to increase disease occurrence, which incorporates modifiable and non-modifiable risk factors. ${ }^{6,22}$ However, several epidemiological studies conducted in different populations indicate that the incidence and mortality of breast cancer greatly vary between countries. This indicates that environmental and lifestyle factors may contribute to the development of breast cancer. ${ }^{7,22-25}$

Primary prevention offers the greatest public health potential and most cost-effective long-term cancer control program. Approximately $50 \%$ of breast cancers could be prevented when a maximal benefit is achieved through prevention programs and lifestyle modification., 2,20,26 However, adequate information is not available to validate specific lifestyle modification programs, especially in LMICs. ${ }^{2,20,26}$ Additionally, effective programs to prevent the onset of breast cancer have not been a priority for the health systems in LMICs, including Ethiopia, and there is a lack of awareness of the risk factors of cancer. ${ }^{16}$

A study conducted in Africa on the management of breast cancer suggests that there is a research gap in LMICs. ${ }^{27}$ The population of women in Ethiopia is diverse, with different lifestyle factors, cultures, economic statuses, and reproductive and breastfeeding practices. These factors affect the overall health conditions and make it an area of interest for investigating risk factors of breast cancer. Moreover, studies focused on identifying the risk factors in a local context play an important role in the prevention of breast cancer and would contribute to the prioritization of interventions. ${ }^{10,18}$ Despite the abovementioned geographic and behavioral variation in breast cancer risk and increased incidence rate in low-income countries, including Ethiopia. There is a paucity of studies on risk factors of breast cancer in Ethiopia. Therefore, this study aimed to identify the risk factors associated with breast cancer among women attending Tikur Anbessa Specialized Hospital (TASH) and St. Paul's Hospital Millennium Medical College (SPHMMC), Addis Ababa, Ethiopia, 2020.

\section{Materials and Methods Study Setting and Population}

The study participants were recruited from the two most common referral public hospitals (TASH and SPHMMC) in Addis Ababa, Ethiopia. We conducted an institutionalbased unmatched case-control study from February $1^{\text {st }}$ to March 30, 2020. Women who have histologically confirmed breast cancer cases and unmatched noncancerous clients visiting the same hospital in the study period were included. However, women who had cancer from another site and disseminated to the breast, critically ill, and mentally handicapped patients were excluded. All women diagnosed clinically and histologically confirmed breast cancer were eligible for inclusion as cases. A potential control was a woman aged 20 years or older who had no prior history of breast cancer and who was unrelated to cases. Controls were relatively healthy women recruited from maternal and child health unit, family planning, and outpatient units for any illness other than breast cancer in two hospitals.

\section{Sample Size and Procedure}

The sample size was calculated using Epi-Info version 7.2 based on the following assumptions: 95\% confidence 
interval, $80 \%$ power, and 1:2 ratio of cases to controls, $24.3 \%$ proportion of family history of breast cancer in Senegal Dakar with an odds ratio of $2.12^{28}$ and a $10 \%$ non-response rate. This yields a maximum sample size of 116 cases and 232 controls. The hospitals were selected purposively because more than $90 \%$ of breast cancer patients were attending the oncology unit in these Hospitals in Addis Ababa, Ethiopia. The sample size was allocated using probability proportional to size based on the proportion of average monthly client flow reviewed from the registration book. Cases were selected for all women with confirmed breast cancer attending two hospitals during the two-month data collection period until the final sample size was reached. For every case, two controls were selected among healthy women between ages 20 to 74 years using systematic random sampling methods.

\section{Data Collection Procedure}

All participants were interviewed by trained interviewers at the hospitals. Data were collected by 6 nurses using a pretested, interviewer-administered questionnaire that was adapted and modified from published literature. ${ }^{29,30}$ The questionnaires were translated into Amharic version, and then translated back to English to ensure its consistency. The questionnaire includes sociodemographic characteristics and behavioral, reproductive, and biological related factors. We defined women who had sisters or mothers or daughters with breast cancer were categorized as having a first-degree family history of breast cancer. Post-menopausal status was defined as no menses for the past one year. The participants were categorized as parous if they had at least one full-term pregnancy (live or stillbirth). The weight scale was calibrated at 0 with no object on it and placed on the level surface before the measurement was carried out. Height was measured with a stadiometer attached to the wall. A continuous checkup of the scale was performed for reliability. Body mass index (BMI) was calculated by BMI = weight $(\mathrm{kg}) /$ height square (M2). A BMI of 25.0 or more is overweight, more than 30 is obese, while the healthy range is 18.5 to 24.9 .

\section{Data Quality Control}

Two days training was given to all the data collectors and supervisors. A pretest was carried out on 5\% (in Zewuditu Hospital) of the total sample size before the actual data collection. Based on the findings of the pretest, some modifications were undertaken. The data collection process was closely supervised, and the completeness of each questionnaire was checked daily. During data cleaning, a logical checking technique was employed to identify errors. Finally, double data entry was performed to check the consistency of the data.

\section{Data Processing Analysis}

The data were entered into Epi Data version 4.6 and analyzed using Statistical Package for the Social Sciences (SPSS) Version 25. Descriptive statistics including frequencies and proportions were employed. The findings were presented using tables, figures, and graphs. Multivariable logistic regression was used to measure the association between covariates and outcome variable. Adjusting for potential confounders factors, the models were adjusted for age, anthropometric, lifestyle variables, age of menarche, age of menopause, and family history of breast cancer, were added when appropriate. Multicollinearity was checked to see the linear correlation among the independent variables by using variance inflation factor $(>10)$ and standard error $(>2)$ and goodness-offit was checked by Hosmer-Lemeshow test $(>0.05)$. Adjusted odds ratio (AOR) with 95\% confidence intervals (CI) using a p-value $<0.05$ was considered a statistically significant association with the outcome variable.

\section{Results \\ Sociodemographic Characteristics}

A total of 116 cases and 232 controls participated in the study, with a response rate of $100.0 \%$. The mean $( \pm$ SD) age of the participants was $42.7( \pm 11.3)$ and $40.7( \pm 14.6)$ for cases and controls, respectively. Of the participants, 67 (57.4\%) cases and $96(41.2 \%)$ controls were recruited from TASH. Ninety-eight (84.5\%) cases and 223 (96.1\%) controls were urban dwellers. Of these, more than half 98 $(84.5 \%)$ of the cases and $162(69.8 \%)$ controls were from Addis Ababa. Thirty-seven (31.9\%) cases and 84 (36.2\%) controls had college and above educational status. Regarding occupational status, 50 (43.1\%) cases, and 91 $(39.2 \%)$ controls were employed. More than half $(55.5 \%)$ of the participants earn greater than 2000 Ethiopian birr (ETB) per month (Table 1).

\section{Behavioral and Biological-Related Characteristics}

Among the total participants, 37 (31.9\%) cases and 58 $(25.0 \%)$ controls had overweight and/or obesity. Among the study participants, 23 (19.8\%) cases and 29 (12.5\%) 
Table I Sociodemographic Characteristics of Women among Cases and Controls at TASH and SPHMMC Addis Ababa, Ethiopia, 2020

\begin{tabular}{|c|c|c|c|}
\hline Variables & $\begin{array}{l}\text { Controls } \\
(n=232)\end{array}$ & $\begin{array}{l}\text { Cases } \\
(n=\mid 16)\end{array}$ & $\begin{array}{l}\text { Total } \\
(n=348)\end{array}$ \\
\hline & Count (\%) & Count (\%) & Count (\%) \\
\hline $\begin{array}{l}\text { Place of residence } \\
\text { Urban } \\
\text { Rural }\end{array}$ & $\begin{array}{l}223(96.1) \\
9(3.9)\end{array}$ & $\begin{array}{l}98(84.5) \\
18(15.5)\end{array}$ & $\begin{array}{l}32 \mathrm{I}(92.2) \\
27(7.8)\end{array}$ \\
\hline $\begin{array}{l}\text { Region } \\
\text { Addis Ababa } \\
\text { Oromia } \\
\text { Amhara } \\
\text { Others }\end{array}$ & $\begin{array}{l}162(69.8) \\
45(19.4) \\
20(8.6) \\
5(2.2)\end{array}$ & $\begin{array}{l}98(84.5) \\
10(8.6) \\
5(4.3) \\
3(2.6)\end{array}$ & $\begin{array}{l}260(76.1) \\
55(14.9) \\
25(7.2) \\
8(1.7)\end{array}$ \\
\hline $\begin{array}{l}\text { Educational status } \\
\text { No formal } \\
\text { education } \\
\text { Primary } \\
\text { Secondary } \\
\text { College and above }\end{array}$ & $\begin{array}{l}39(16.8) \\
76(32.8) \\
33(14.2) \\
84(36.2)\end{array}$ & $\begin{array}{l}27(23.3) \\
33(28.4) \\
19(16.4) \\
37(31.9)\end{array}$ & $\begin{array}{l}66(19.0) \\
109(31.3) \\
52(14.9) \\
121(34.8)\end{array}$ \\
\hline $\begin{array}{l}\text { Marital status } \\
\text { Married } \\
\text { Widowed } \\
\text { Divorced } \\
\text { Single }\end{array}$ & $\begin{array}{l}\text { I } 35(58.2) \\
28(12.1) \\
I I(4.7) \\
58(25.0)\end{array}$ & $\begin{array}{l}84(72.4) \\
8(6.9) \\
10(8.6) \\
14(12.1)\end{array}$ & $\begin{array}{l}219(62.9) \\
36(10.3) \\
21(6.0) \\
72(20.7)\end{array}$ \\
\hline $\begin{array}{c}\text { Occupation } \\
\text { House wife } \\
\text { Employed } \\
\text { Merchant } \\
\text { Farmer }\end{array}$ & $\begin{array}{l}106(45.7) \\
91(39.2) \\
12(5.2) \\
23(9.9)\end{array}$ & $\begin{array}{l}55(47.4) \\
50(43.1) \\
3(2.6) \\
8(6.9)\end{array}$ & $\begin{array}{l}|6|(46.3) \\
|4|(40.5) \\
15(4.2) \\
3 \mid(9.0)\end{array}$ \\
\hline $\begin{array}{l}\text { Family monthly } \\
\text { income } \\
\quad \leq 1000 \\
1001-1999 \\
\geq 2000 \text { ETB }\end{array}$ & $\begin{array}{l}62(26.7) \\
36(15.5) \\
134(57.8)\end{array}$ & $\begin{array}{l}37(31.9) \\
20(17.2) \\
59(50.9)\end{array}$ & $\begin{array}{l}99(28.4) \\
56(16.1) \\
193(55.5)\end{array}$ \\
\hline
\end{tabular}

controls had a family history of cancers. Regarding physical activities, in most cases, 98 (84.5\%) and 198 (85.3\%) controls did not participate in regular physical exercise. More than half of the cases $79(68.1 \%)$ and $132(56.9 \%)$ controls eat less than seven servings of fruits and vegetables per week. Regarding exposure to smoked meat, $58(50.0 \%)$ cases, and $70(30.2 \%)$ controls were exposed. Thirty-nine $(33.6 \%)$ cases and 46 (19.8\%) controls used packed food or drinks. The majority of the participants, $84(72.4 \%)$ cases and 181 (78.0\%) control had no history of breast trauma (Table 2).
Table 2 Behavioral and Biological Related Characteristics of Women among Cases and Controls at TASH and SPHMMC Addis Ababa, Ethiopia, 2020

\begin{tabular}{|c|c|c|c|}
\hline Variables & $\begin{array}{l}\text { Controls } \\
(n=232)\end{array}$ & $\begin{array}{l}\text { Cases } \\
(n=\mid 16)\end{array}$ & $\begin{array}{l}\text { Total } \\
(n=348)\end{array}$ \\
\hline & $\begin{array}{l}\text { Count } \\
\text { (\%) }\end{array}$ & $\begin{array}{l}\text { Count } \\
\text { (\%) }\end{array}$ & $\begin{array}{l}\text { Count } \\
\text { (\%) }\end{array}$ \\
\hline $\begin{array}{l}\text { BMI } \\
\text { Underweight } \\
\text { Normal weight } \\
\text { Overweight and/or } \\
\text { Obesity }\end{array}$ & $\begin{array}{l}15(6.5) \\
159(68.5) \\
58(25.0)\end{array}$ & $\begin{array}{l}10(8.6) \\
69(59.5) \\
37(31.9)\end{array}$ & $\begin{array}{l}25(7.2) \\
228(65.5) \\
95(27.3)\end{array}$ \\
\hline $\begin{array}{l}\text { Physical activity } \\
\text { Yes } \\
\text { No }\end{array}$ & $\begin{array}{l}34(14.7) \\
198(85.3)\end{array}$ & $\begin{array}{l}18(15.5) \\
98(84.5)\end{array}$ & $\begin{array}{l}52(14.9) \\
296(85.1)\end{array}$ \\
\hline $\begin{array}{l}\text { Intensity of activity } \\
\text { Light } \\
\text { Moderate } \\
\text { Heavy }\end{array}$ & $\begin{array}{l}\text { I7 (50.0) } \\
\text { I4 (4I.2) } \\
3(8.8)\end{array}$ & $\begin{array}{l}10(55.6) \\
6(33.3) \\
5(11.1)\end{array}$ & $\begin{array}{l}27(51.9) \\
20(38.5) \\
8(9.6)\end{array}$ \\
\hline $\begin{array}{l}\text { Vegetable or fruit } \\
\text { intake per week } \\
\quad \leq 7 \\
>7\end{array}$ & $\begin{array}{l}132(56.9) \\
100(43.1)\end{array}$ & $\begin{array}{l}79(68.1) \\
37(31.9)\end{array}$ & $\begin{array}{l}211(60.6) \\
137(39.4)\end{array}$ \\
\hline $\begin{array}{l}\text { Exposure to smoked } \\
\text { meat } \\
\text { Yes } \\
\text { No }\end{array}$ & $\begin{array}{l}70(30.2) \\
162(69.8)\end{array}$ & $\begin{array}{l}58(50.0) \\
58(50.0)\end{array}$ & $\begin{array}{l}128(36.8) \\
220(63.2)\end{array}$ \\
\hline $\begin{array}{l}\text { Packed food } \\
\text { consumption } \\
\text { Yes } \\
\text { No }\end{array}$ & $\begin{array}{l}46(19.8) \\
186(80.2)\end{array}$ & $\begin{array}{l}39(33.6) \\
77(66.4)\end{array}$ & $\begin{array}{l}85(24.4) \\
263(75.6)\end{array}$ \\
\hline $\begin{array}{l}\text { History of trauma to } \\
\text { the breast } \\
\text { Yes } \\
\text { No }\end{array}$ & $\begin{array}{l}51(22.0) \\
|8|(78.0)\end{array}$ & $\begin{array}{l}32(27.6) \\
84(72.4)\end{array}$ & $\begin{array}{l}83(23.9) \\
265(76.1)\end{array}$ \\
\hline $\begin{array}{l}\text { Ever had a mammogram } \\
\text { Yes } \\
\text { No }\end{array}$ & $\begin{array}{l}5(2.2) \\
227(97.8)\end{array}$ & $\begin{array}{l}7(6.0) \\
109(94.0)\end{array}$ & $\begin{array}{l}12(3.4) \\
336(96.6)\end{array}$ \\
\hline $\begin{array}{l}\text { Breast self-examination } \\
\text { Yes } \\
\text { No }\end{array}$ & $\begin{array}{l}94(40.5) \\
138(59.5)\end{array}$ & $\begin{array}{l}46(39.7) \\
70(60.3)\end{array}$ & $\begin{array}{l}140(40.2) \\
208(59.8)\end{array}$ \\
\hline
\end{tabular}

\section{Reproductive Health-Related}

\section{Characteristics}

Among participants, 40 (34.5\%) cases and 27 (11.6\%) controls had seen their first menstrual period before the age of 12 years (Figure 1). Sixty (44.1\%) cases and 53 


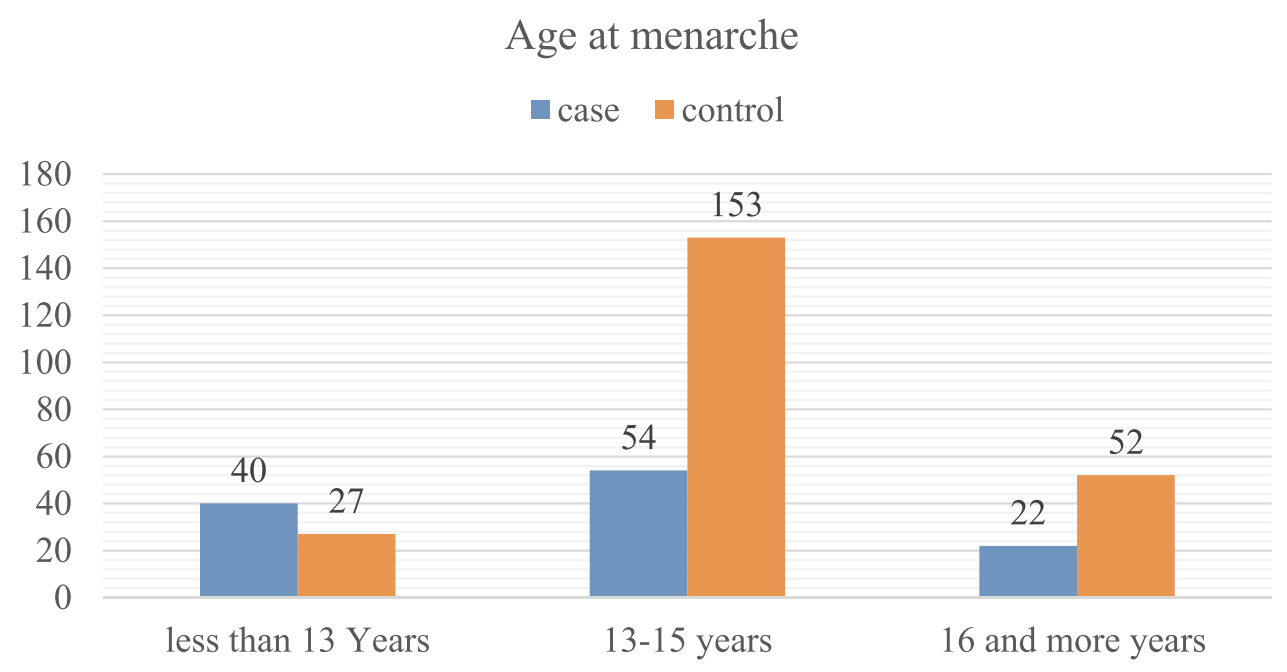

Figure I Distribution of women with age at menarche among cases and controls at TASH and SPHMMC Addis Ababa, Ethiopia, 2020.

(39.0\%) controls had a history of using contraceptives, nearly half $(47.5 \%)$ of the cases and $21(39.6 \%)$ controls used Oral contraceptives. Seventy-eight (67.2\%) cases 181 (78.0\%) controls had no history of abortion. From a total of women, the majority of cases $94(81.0 \%)$ and 180 (77.6\%) controls had ever breastfed their infants (Table 3).

\section{Factors Associated with Breast Cancer Risk}

In the multivariable logistic regression analysis, place of residence, use of packed foods or drinks, exposure to smoked-dried meat, age at menarche, BMI, family history of cancer, and having less than one child were independently associated with breast cancer risk. The risk of breast cancer was higher among rural women $(\mathrm{AOR}=3.64 ; 95 \%$ CI: $1.38,9.57)$ than women who lived in urban areas. Women who used packed foods or drinks were nearly 3 times $(\mathrm{AOR}=2.80 ; 95 \% \mathrm{CI}: 1.52,5.15)$ more likely to have breast cancer risk compared with their counterparts. Similarly, women who utilized smoke-dried meat were 2.41 times $(\mathrm{AOR}=2.41 ; 95 \% \mathrm{CI}: 1.36,4.27)$ more likely to have breast cancer risk compared with their counterparts. Women with a family history of cancer were 2 times $\mathrm{AOR}=2.11 ; 95 \% \mathrm{CI}: 1.04,4.26)$ more likely to be affected with breast cancer than their counterparts. Furthermore, women who had seen their first menstrual period before the age of 12 were almost 4 times $(\mathrm{AOR}=4.10 ; 95 \% \mathrm{CI}$ : $1.84,9.15)$ more likely to have breast cancer risk compared with those women who had seen after the age of 12 years. Moreover, women who were overweight or obese were 2.38 times $(\mathrm{AOR}=2.38 ; 95 \% \mathrm{CI}: 1.31,4.31)$ higher chance of getting the risk of breast cancer compared with the normal-weight women. Also, women with one or less child were 1.86 times (AOR=1.86; 95\% CI: 1.01, 3.41) more likely to get the risk of breast cancer (Table 4).

\section{Discussion}

The identification of modifiable factors in the local context may contribute to the development of prevention strategies that decrease breast cancer incidence and mortality. ${ }^{31,32}$ To our knowledge, this study was the first to investigate breast cancer risk in Ethiopian women. The present study identified that rural residence, early onset of menarche, use of packed foods or drinks, smoked dried meat, BMI, family history of cancer, and less than one child were independently associated with the breast cancer risk.

In this finding, the place of residence had a significant association with breast cancer risk. The odds of breast cancer were approximately 4 times higher among women who were living in rural areas. This is consistent with a study conducted in the Central African Republic that showed that decreased odds of breast cancer were associated with living in urban areas. ${ }^{31}$ However, it is inconsistent with the systematic review and meta-analysis indicating that residing in urban areas is associated with higher breast cancer incidence. ${ }^{33}$ This might be due to differences in the economic condition of the population, educational status, and better awareness of risk factors in urban areas.

The risk of breast cancer may be reduced to the extent that one can make lifestyle changes consistent 
Table 3 Reproductive Health-Related Characteristics of Women among Cases and Controls at TASH and SPHMMC Addis Ababa, Ethiopia, 2020

\begin{tabular}{|c|c|c|c|}
\hline \multirow[t]{2}{*}{ Variables } & $\begin{array}{l}\text { Controls } \\
(n=232)\end{array}$ & $\begin{array}{l}\text { Cases } \\
(n=116)\end{array}$ & $\begin{array}{l}\text { Total } \\
(n=348)\end{array}$ \\
\hline & Count (\%) & Count (\%) & Count (\%) \\
\hline \multicolumn{4}{|l|}{$\begin{array}{l}\text { Menstrual period } \\
\text { regularity }\end{array}$} \\
\hline Yes & $208(89.7)$ & $93(80.2)$ & $301(86.5)$ \\
\hline No & $24(10.3)$ & $23(19.8)$ & $47(13.5)$ \\
\hline \multicolumn{4}{|l|}{ Menopausal status } \\
\hline Premenopausal & I 48 (63.8\%) & $60(51.7)$ & $208(59.8)$ \\
\hline Menopausal & $84(36.2)$ & $56(48.3)$ & $140(40.2)$ \\
\hline \multicolumn{4}{|l|}{ Age at menopause } \\
\hline$\leq 45$ years & $58(69.0)$ & $37(66.1)$ & $95(67.9)$ \\
\hline $46-54$ years & $24(28.6)$ & $19(33.9)$ & $43(30.7)$ \\
\hline$\geq 55$ years & $2(2.4)$ & $0(0.0)$ & $2(1.4)$ \\
\hline \multicolumn{4}{|l|}{$\begin{array}{l}\text { Duration of } \\
\text { contraceptive use }\end{array}$} \\
\hline$\leq 4$ years & $50(54.9)$ & $25(52.1)$ & $75(54.0)$ \\
\hline$>4$ years & $4 I(45.1)$ & $23(47.9)$ & $64(46.0)$ \\
\hline \multicolumn{4}{|l|}{ Age at first live birth } \\
\hline$\leq 20$ years & $67(46.2)$ & $33(39.3)$ & $100(43.7)$ \\
\hline $21-29$ years & $58(40.0)$ & $38(45.2)$ & $96(41.9)$ \\
\hline$\geq 30$ years & $20(13.8)$ & $13(15.5)$ & $33(14.4)$ \\
\hline \multicolumn{4}{|l|}{ History of abortion } \\
\hline Yes & $51(22.0)$ & $38(32.8)$ & $89(25.6)$ \\
\hline No & I8I (78.0) & $78(67.2)$ & $259(74.4)$ \\
\hline \multicolumn{4}{|l|}{ Breastfeeding } \\
\hline Yes & $180(77.6)$ & $94(81.0)$ & $274(78.7)$ \\
\hline No & $52(22.4)$ & $22(19.0)$ & $74(21.3)$ \\
\hline
\end{tabular}

with modifiable risk factors. ${ }^{34}$ According to this study, women who have used packed foods or drinks were nearly 3 times more likely to have breast cancer risk. This finding is supported by studies conducted in Iran that identified that the consumption of soft drinks and industrially produced juices was associated with a significantly increased risk of breast cancer. ${ }^{35,36}$ Highly processed foods such as packaged foods, instant soups, reconstituted meats, frozen meals, and shelfstable snacks also contain substances that may significantly increase the overall risk for cancer and breast cancer. $^{37}$ Moreover, exposure to smoke-dried meat increases breast cancer risk by 2 times. This finding is supported by studies that indicated processed meat intake was associated with increased breast cancer risk and statistically associated with an elevated risk of allcause mortality. ${ }^{38-40}$

Furthermore, the risk of breast cancer was positively associated with overweight and/or obesity. This finding is in agreement with many findings. ${ }^{41-44}$ Even though, the exact mechanism behind the association between BMI and breast cancer risk is uncertain, there are some potential hypotheses. The positive association between BMI and breast cancer risk in women was speculated to result from the increased estrogens and inflammatory mediators within the larger fat reserves of women of higher BMI and contribute to the aggressive breast cancer phenotype in overweight and obesity. ${ }^{42,45,46}$

Most of the well-known risk factors for breast cancer are related to the reproductive life of women: Women with early menarche (before age 12 years) have a higher breast cancer risk. ${ }^{47}$ The present study found that the odds of breast cancer increase by 4 times among women with early menarche, which is consistent with studies conducted in India and Morocco. ${ }^{48,49}$ This might be due to a woman's risk of breast cancer being related to the estrogen and progesterone made by her ovaries (known as endogenous estrogen and progesterone). Being exposed for a long time and/or to high levels of these hormones has been linked to an increased risk of breast cancer. In the present findings, contraceptive use did not show a significant association with breast cancer. However, a study in Saudi $\mathrm{Arabia}^{50}$ and Kazakhstan ${ }^{51}$ showed that the odds of breast cancer were higher among women with long-term use of hormonal contraception. Furthermore, this study revealed that women with fewer children (none or one) increases breast cancer risk. This finding is supported by a similar study conducted in Vietnam. ${ }^{52}$ We found a history of abortion as a risk factor for breast cancer in crude analysis. This is in line with a study that justified abortion disrupts the maturation process of the breast, it has increased breast cancer risk. ${ }^{34}$ Besides, null or low parity was related to a higher risk of breast cancer in young women in southern $\operatorname{Iran}^{53}$ and Morocco. ${ }^{49}$ However, in the current study, parity, age at first live birth, and history of breastfeeding did not show a significant association with breast cancer. This difference might be due to the smaller sample size and poor age recording keeping system in the country.

Family history is an important risk factor for breast cancer and is significantly greater in women with a family history of the disease. ${ }^{24,28,54}$ Similarly, in this study, family history has significantly associated with the risk of breast cancer. However, this finding is in contrast with 
Table 4 Bivariable and Multivariable Logistic Regression Analysis of Factors Associated with Breast Cancer Risk at TASH and SPHMMC Addis Ababa, Ethiopia, 2020

\begin{tabular}{|c|c|c|c|c|c|c|}
\hline \multirow[t]{2}{*}{ Variables } & \multirow[b]{2}{*}{ Categories } & \multicolumn{2}{|c|}{ Breast Cancer } & \multirow[t]{2}{*}{ COR $(95 \% \mathrm{Cl})$} & \multirow[t]{2}{*}{ AOR $(95 \% \mathrm{Cl})$} & \multirow[t]{2}{*}{ P-value } \\
\hline & & $\begin{array}{l}\text { Control } \\
(n=232)\end{array}$ & $\begin{array}{l}\text { Cases } \\
(n=116)\end{array}$ & & & \\
\hline Place of residence & $\begin{array}{l}\text { Urban } \\
\text { Rural }\end{array}$ & $\begin{array}{l}223 \\
9\end{array}$ & $\begin{array}{l}98 \\
18\end{array}$ & $\begin{array}{l}1.00 \\
4.55(1.97,10.49)\end{array}$ & $\begin{array}{l}1.00 \\
3.64(1.38,9.57)^{*}\end{array}$ & 0.009 \\
\hline Smoked meat exposure & $\begin{array}{l}\text { Yes } \\
\text { No }\end{array}$ & $\begin{array}{l}70 \\
162\end{array}$ & $\begin{array}{l}58 \\
58\end{array}$ & $\begin{array}{l}2.31(1.46,3.66) \\
1.00\end{array}$ & $\begin{array}{l}2.4 \mathrm{I}(1.36,4.27)^{*} \\
1.00\end{array}$ & 0.003 \\
\hline Use of packed food or drinks & $\begin{array}{l}\text { Yes } \\
\text { No }\end{array}$ & $\begin{array}{l}46 \\
186\end{array}$ & $\begin{array}{l}39 \\
77\end{array}$ & $\begin{array}{l}2.05(1.24,3.39) \\
1.00\end{array}$ & $\begin{array}{l}2.80(1.52,5.15)^{*} \\
1.00\end{array}$ & 0.001 \\
\hline $\begin{array}{l}\text { Vegetable consumptions per } \\
\text { week }\end{array}$ & $\begin{array}{l}\text { Less than } 7 \\
7 \text { and more }\end{array}$ & $\begin{array}{l}132 \\
100\end{array}$ & $\begin{array}{l}79 \\
37\end{array}$ & $\begin{array}{l}1.62(1.01,2.59) \\
1.00\end{array}$ & $\begin{array}{l}1.36(0.75,2.45) \\
1.00\end{array}$ & 0.315 \\
\hline Age at menarche in years & $\begin{array}{l}\leq 12 \\
13-15 \\
\geq 16\end{array}$ & $\begin{array}{l}27 \\
153 \\
52\end{array}$ & $\begin{array}{l}40 \\
54 \\
22\end{array}$ & $\begin{array}{l}3.50(1.74,7.03) \\
0.83(0.46,1.50) \\
1.00\end{array}$ & $\begin{array}{l}4.10(1.84,9.15)^{*} \\
1.06(0.56,2.02) \\
1.00\end{array}$ & $\begin{array}{l}0.001 \\
0.86 I\end{array}$ \\
\hline Menstrual regularity & $\begin{array}{l}\text { Yes } \\
\text { No }\end{array}$ & $\begin{array}{l}208 \\
24\end{array}$ & $\begin{array}{l}93 \\
23\end{array}$ & $\begin{array}{l}1.00 \\
2.14(1.15,3.99)\end{array}$ & $\begin{array}{l}1.00 \\
1.38(0.67,2.85)\end{array}$ & 0.384 \\
\hline BMI & $\begin{array}{l}\text { Underweight } \\
\text { Overweight and obesity } \\
\text { Normal weight }\end{array}$ & $\begin{array}{l}15 \\
58 \\
159\end{array}$ & $\begin{array}{l}10 \\
37 \\
69\end{array}$ & $\begin{array}{l}I .54(0.66,3.59) \\
I .47(0.89,2.42) \\
I .00\end{array}$ & $\begin{array}{l}\mathrm{I} .44(0.53,3.9 \mathrm{I})^{*} \\
2.38(\mathrm{I} .3 \mathrm{I}, 4.3 \mathrm{I}) \\
\mathrm{I} .00\end{array}$ & $\begin{array}{l}0.474 \\
0.004\end{array}$ \\
\hline Number of children & $\begin{array}{l}\text { One or less } \\
\text { Two and more }\end{array}$ & $\begin{array}{l}138 \\
94\end{array}$ & $\begin{array}{l}81 \\
35\end{array}$ & $\begin{array}{l}1.57(0.98,2.54) \\
1.00\end{array}$ & $\begin{array}{l}\mathrm{I} .86(\mathrm{I} .0 \mathrm{I}, 3.4 \mathrm{I})^{*} \\
\mathrm{I} .00\end{array}$ & 0.046 \\
\hline Educational status & $\begin{array}{l}\text { No formal education } \\
\text { Primary and secondary } \\
\text { education } \\
\text { College and above }\end{array}$ & $\begin{array}{l}39 \\
109 \\
84\end{array}$ & $\begin{array}{l}27 \\
52 \\
37\end{array}$ & $\begin{array}{l}1.57(0.84,2.94) \\
1.08(0.65,1.80) \\
1.00\end{array}$ & $\begin{array}{l}\text { I.69 }(0.75,3.84) \\
\text { I.II }(0.60,2.03) \\
I .00\end{array}$ & $\begin{array}{l}0.209 \\
0.733\end{array}$ \\
\hline History of abortion & $\begin{array}{l}\text { Yes } \\
\text { No }\end{array}$ & $\begin{array}{l}51 \\
181\end{array}$ & $\begin{array}{l}38 \\
78\end{array}$ & $\begin{array}{l}1.73(1.05,2.84) \\
1.00\end{array}$ & $\begin{array}{l}1.50(0.84,2.70) \\
1.00\end{array}$ & 0.168 \\
\hline Family history of Cancer & $\begin{array}{l}\text { Yes } \\
\text { No }\end{array}$ & $\begin{array}{l}29 \\
203\end{array}$ & $\begin{array}{l}23 \\
93\end{array}$ & $\begin{array}{l}1.73(0.95,3.15) \\
1.00\end{array}$ & $\begin{array}{l}2.11(1.04,4.26)^{*} \\
1.00\end{array}$ & 0.038 \\
\hline
\end{tabular}

Note: *Statistically significant at $P \leq 0.05$.

Abbreviations: COR, crude odds ratio; AOR, adjusted odds ratio.

the results of a previous similar study conducted in Vietnam, which indicated that there was no significant association between family history and breast cancer. ${ }^{55}$ Further studies with high-level methodology may be needed to solicit the association between family history and risk of breast cancer.

Limitation of the study: This case-control study cannot determine cause and effect relationships. The findings of this study were based on self-report, as it was not possible to validate claims obtained from study subjects that could be subject to recall bias. A wide confidence interval is noted in some of the variables as a result of a small sample size.

\section{Conclusion}

In conclusion, factors such as the early onset of menarche, rural women, utilization of packed foods or drinks and smoke-dried meat, family history of cancer, overweight and/or obesity, and women with one or less child were factors which increased the risk of breast cancer. Therefore, focusing on modifiable risk factors and increasing awareness of the community such as a healthy diet and promotion of breast self-examination, and the creation of programs to increase women's knowledge is important to reduce the increasing burden of breast cancer in the study setting. Further studies with larger sample sizes and high- 
level study designs are recommended to better understand the local risk factors.

\section{Data Sharing Statement}

All the data of this study are available from the corresponding author upon reasonable request.

\section{Ethics Approval and Consent to Participate}

This study was conducted in accordance with the declaration of Helsinki. Ethical clearance was obtained from the Institutional Health Research Ethics Review Committee of the College of Health Sciences, Addis Ababa University (Ref. No. 047/20/SNM). Following approval, a written official letter of cooperation was given to the administrative health bureau and facilities. Informed written consent was obtained from all participants. Furthermore, confidentiality was assured throughout the process.

\section{Acknowledgments}

We would like to thank Addis Ababa University for its financial and unreserved technical support. We would also like to extend our gratitude to the hospital heads, the study participants, the data collectors, and the supervisor for collaborations.

\section{Author Contributions}

All authors made a significant contribution in the conception, study design, execution, acquisition of data, analysis, and interpretation; took part in drafting, revising, or critically for important intellectual content; gave final approval of the version to be published; have agreed on the journal to which the article has been submitted; and agree to be accountable for all aspects of the work.

\section{Funding}

This work was financially supported by Addis Ababa University, Ethiopia. The funder has no role in the study selection, data collection, analysis, conclusion, and interpretation.

\section{Disclosure}

The authors declare that they have no competing interests.

\section{References}

1. IA for $\mathrm{R}$ on $\mathrm{C}$ (IARC). Latest global cancer data: cancer burden rises to 18.1 million new cases and 9.6 million cancer deaths in 2018. CA Cancer J Clin. 2018;(September):13-15.
2. Registry IA for R on CG 2018 WHO cancer data C. New Global Cancer Data: GLOBOCAN 2018 | UICC. Int Agency Res Cancer. 2018(September): 1 .

3. World Health Organization. WHO | breast cancer. Who. 2018. Available from: https:/www.who.int/cancer/prevention/diagnosisscreening/breast-cancer/en/. Accessed January 5, 2021.

4. Jemal A, Bray F, Ferlay J. Global cancer statistics: 2011. CA Cancer J Clin. 2011;49(2):1, 33-64. doi:10.3322/caac.20107

5. American Cancer Society. About breast cancer. Breast Cancer Facts Fig. 2017:1-19. Available from: https://www.cancer.org/content/dam/ CRC/PDF/Public/8577.00.pdf\%0Ahttp://www.breastcancer.org/symp toms/understand_bc/what_is_bc. Accessed January 5, 2021.

6. American Cancer Society. Cancer facts \& figures 2019. Atlanta: American Cancer Society; 2019:1-76. https://www.cancer.org/con tent/dam/cancer-org/research/cancer-facts-and-statistics/annualcancer-facts-and-figures/2019/cancer-facts-and-figures-2019.pdf.

7. American Cancer Society. American Cancer Society. Global Cancer Facts \& Figures 4th Edition. Atlanta; American Cancer Society: 2018. 1-76

8. Shulman LN, Willett W, Sievers A, Knaul FM. Breast cancer in developing countries: opportunities for improved survival. J Oncol. 2010;2010. doi:10.1155/2010/595167.

9. Sylla BS, Wild CP. Cancer burden in Africa in 2030: invest today and save tomorrow. J Africain Du Cancer. 2012;4(1):1-2. doi:10.1007/ s12558-012-0199-4

10. Azubuike SO, Muirhead C, Hayes L, McNally R. Rising global burden of breast cancer: the case of sub-Saharan Africa (with emphasis on Nigeria) and implications for regional development: a review. World J Surg Oncol. 2018;16(1):1-13. doi:10.1186/s12957-018$1345-2$

11. Timotewos G, Solomon A, Mathewos A, et al. First data from a population-based cancer registry in Ethiopia. Cancer Epidemiol. 2018;53(October2017):93-98. doi:10.1016/j.canep.2018.01.008

12. Memirie ST, Habtemariam MK, Asefa M, et al. Estimates of cancer incidence in Ethiopia in 2015 using population-based registry data. J Glob Oncol. 2018;2018:4. doi:10.1200/JGO.17.00175

13. SM A. Trends of breast cancer in Ethiopia. Int $J$ Cancer Res Mol Mech. 2016;2(1):2-6. doi:10.16966/2381-3318.121

14. Al-Azri M, Al-Awisi H, Al-Rasbi S, et al. Psychosocial impact of breast cancer diagnosis among Omani women. Oman Med J. 2014;29 (6):437-444. doi:10.5001/omj.2014.115

15. Breast Cancer Network Australia (BCNA). The financial impact of breast cancer. 2018:1-19. bena.org.au.

16. FMoH. National Cancer Control Plan 2016-2020 of Ethiopia. Dis Prev Control Dir. 2015;(October 2015):83.

17. Horton S, Gauvreau CL. Cancer in Low- and Middle-Income Countries: An Economic Overview. In: Gelband H, Jha P, Sankaranarayanan R, Horton S, editors. Cancer: Disease Control Priorities, Third Edition (Volume 3). Washington (DC): The International Bank for Reconstruction and Development / The World Bank; 2015 Nov 1. Chapter 16. doi:10.1596/978-1-46480349-9_ch16.

18. Iqbal MS, Hossain MS, Niessen LW. Breast cancer in low-resource settings: prioritizing the awareness and access programs to overcome sociocultural and economic barriers for early detection and improved outcomes. Eur J Cancer Prev. 2014;23(4):286-287. doi:10.1097/ CEJ.0000000000000043

19. WHO. Global Health Risks: mortality and burden of disease attributable to selected major risks. 2009:1-70. http://www.who.int/ healthinfo/global_burden_disease/GlobalHealthRisks_report_full. pdf.

20. American Cancer Society. Breast cancer risk and prevention breast cancer risk factors you cannot change. Cancer Org. 2020;1-45.

21. WCRF International. WCRFI for CR. Diet, nutrition, physical activity, and breast cancer. Contin Update Proj Expert Rep. 2018;2018:50. doi:10.1007/s12082-007-0105-4 
22. American Cancer Society. Breast cancer breast facts \& figures 20192020. 2020; 1-43. doi:10.1007/174_2016_83

23. Tan MM, Ho WK, Yoon SY, et al. A case-control study of breast cancer risk factors in 7,663 women in Malaysia. PLoS One. 2018;13 (9):1-12. doi:10.1371/journal.pone.0203469

24. Liu LY, Wang F, De CS, et al. A case-control study on risk factors of breast cancer in Han Chinese women. Oncotarget. 2017;8 (57):97217-97230. doi:10.18632/ontarget.21743

25. Sepandi M, Akrami M, Tabatabaee H, et al. Breast cancer risk factors in women participating in a breast screening program: a study on 11,850 Iranian females. Asian Pacific J Cancer Prev. 2014;15 (19):8499-8502. doi:10.7314/APJCP.2014.15.19.8499

26. Howell A, Anderson AS, Clarke RB, et al. Risk determination and prevention of breast cancer. Breast Cancer Res. 2014;16(5):1-19. doi:10.1186/s13058-014-0446-2

27. Vanderpuye V, Grover S, Hammad N, et al. An update on the management of breast cancer in Africa. Infect Agent Cancer. 2017;12(1):1-12. doi:10.1186/s13027-017-0124-y

28. Gueye M, Gueye S, Gueye M, et al. A hospital-based case-control study of female breast cancer risk factors in a Sub-Saharan African country. Int $J$ Reprod Contraception Obstet Gynecol. 2016;5 (7):2328-2332. doi:10.18203/2320-1770.ijrcog20162121

29. Galukande M, Wabinga H, Mirembe F, Karamagi C, Asea A. Breast cancer risk factors among Ugandan women at a tertiary hospital: a case-control study. Oncol. 2016;90(6):356-362. doi:10.1159/000 445379

30. Parkinson MR. Established and suspected risk factors for breast cancer: a case-control study in Vancouver, BC, and Kingston, ON. Unpubl thesis queens., Ontario, Canada: Univ Kingston 2011:24. Available from: http://ridum.umanizales.edu.co:8080/jspui/bitstream/ 6789/377/4/Muñoz_Zapata_Adriana_Patricia_Artículo_2011.pdf. Accessed January $\overline{5}, 2021$.

31. Balekouzou A, Yin P, Pamatika CM, et al. Reproductive risk factors associated with breast cancer in women in Bangui: a case-control study. BMC Women's Health. 2017;17(1):1-9. doi:10.1186/s12905017-0368-0

32. Kamińska M, Ciszewski T, Łopacka-Szatan K, Miotła P, Starosławska E. Breast cancer risk factors. Prz Menopauzalny. 2015;14(3):196-202. doi:10.5114/pm.2015.54346

33. Akinyemiju TF, Genkinger JM, Farhat M, Wilson A, Gary-Webb TL, Tehranifar P. Residential environment and breast cancer incidence and mortality: a systematic review and meta-analysis. BMC Cancer. 2015;15:1. doi:10.1186/s12885-015-1098-Z

34. Ahmed Z. Risk factors in breast cancer: can we change something. MOJ Surg. 2019;7(1):8-12. doi:10.15406/mojs.2019.07.00154

35. Hosseinzadeh M, Ziaei JE, Mahdavi N, et al. Risk factors for breast cancer in Iranian women: a hospital-based case-control study in Tabriz, Iran. J Breast Cancer. 2014;17(3):236-243. doi:10.4048/ jbc.2014.17.3.236

36. Chang YJ, Chang YJ, Hou YC, et al. Is a vegetarian diet associated with a lower risk of breast cancer in Taiwanese women? BMC Public Health. 2017;17(1):1-9. doi:10.1186/s12889-017-4819-1

37. Fiolet T, Srour B, Sellem L, et al. Consumption of ultra-processed foods and cancer risk: results from NutriNet-Santé prospective cohort. BMJ. 2018:360. doi:10.1136/BMJ.k322.

38. Pouchieu C, Deschasaux M, Hercberg S, Druesne-Pecollo N, LatinoMartel P, Touvier M. Prospective association between red and processed meat intakes and breast cancer risk: modulation by antioxidant supplementation in the SU.VI.MAX randomized controlled trial. Int J Epidemiol. 2014;43(5):1583-1592. doi:10.1093/ije/dyu134
39. Parada H, Steck SE, Bradshaw PT, et al. Grilled, barbecued, and smoked meat intake and survival following breast cancer. $J$ Natl Cancer Inst. 2017;109(6):1-8. doi:10.1093/jnci/djw299

40. Johnson IT. The cancer risk is related to meat and meat products. $\mathrm{Br}$ Med Bull. 2017;121(1):73-81. doi:10.1093/bmb/ldw051

41. Awatef M, Olfa G, Kacem M, Sami L, Makram H, Slim BA. Association between body mass index and risk of breast cancer in Tunisian women. Ann Saudi Med. 2011;31(4):393-397. doi:10.4103/ 0256-4947.83211

42. Picon-Ruiz M, Morata-Tarifa C, Valle-Goffin JJ, Friedman ER, Slingerland JM. Obesity and adverse breast cancer risk and outcome: mechanistic insights and strategies for intervention. CA Cancer J Clin. 2017;67(5):378-397. doi:10.3322/caac.21405

43. Gravena AAF, Lopes TCR, de O Demitto M, et al. The obesity and the risk of breast cancer among pre and postmenopausal women. Asian Pacific J Cancer Prev. 2018;19(9):2429-2436. doi:10.22034/ APJCP.2018.19.9.2429

44. Shieh Y, Scott CG, Jensen MR, et al. Body mass index, mammographic density, and breast cancer risk by estrogen receptor subtype. Breast Cancer Res. 2019;21(1):1-9. doi:10.1186/s13058-019-1129-9

45. Goday A, Barneto I, García-Almeida JM, et al. Obesity as a risk factor in cancer: a national consensus of the Spanish Society for the Study of Obesity and the Spanish Society of Medical Oncology. Clin Transl Oncol. 2015;17(10):763-771. doi:10.1007/s12094-015-1306-y

46. Liu K, Zhang W, Dai Z, et al. Association between body mass index and breast cancer risk: evidence-based on a dose-response meta-analysis. Cancer Manag Res. 2018;10:143-151. doi:10.2147/ CMAR.S144619

47. Li K, Anderson G, Viallon V, et al. Risk prediction for estrogen receptor-specific breast cancers in two large prospective cohorts. Breast Cancer Res. 2018;20(1):1-16. doi:10.1186/s13058-018-1073-0

48. Das S, Sen S, Mukherjee A, Chakraborty D, Mondal PK. Risk factors of breast cancer among women in eastern India: a tertiary hospital-based case-control study. Asian Pacific J Cancer Prev. 2012;13(10):4979-4981. doi:10.7314/APJCP.2012.13.10.4979

49. Khalis M, Charbotel B, Chajès V, et al. Menstrual and reproductive factors and risk of breast cancer: a case-control study in the Fez region, Morocco. PLoS One. 2018;13(1):1-12. doi:10.1371/journal. pone. 0191333

50. Alsolami FJ, Azzeh FS, Ghafouri KJ, et al. Determinants of breast cancer in Saudi women from Makkah region: a case-control study (breast cancer risk factors among Saudi women). BMC Public Health. 2019;19(1):1554. doi:10.1186/s12889-019-7942-3

51. Toleutay U, Reznik V, Kalmatayeva Z, Smigelskas K. Risk factors of breast cancer in Kyzylorda oblast of Kazakhstan: a case-control study. Asian Pacific J Cancer Prev. 2013;14(10):5961-5964. doi:10.7314/APJCP.2013.14.10.5961

52. Nguyen J, Le QH, Duong BH, et al. A matched case-control study of risk factors for breast cancer risk in Vietnam. Int J Breast Cancer. 2016;2016(August):2013. doi:10.1155/2016/7164623

53. Ghiasvand R, Maram ES, Tahmasebi S, Tabatabaee SHR. Risk factors for breast cancer among young women in southern Iran. Int J Cancer. 2011;129(6):1443-1449. doi:10.1002/ijc.25748

54. Tazzite A, Jouhadi H, Saiss K, Benider A, Nadifi S. Relationship between family history of breast cancer and clinicopathological features in Moroccan patients. Ethiop J Health Sci. 2013;23(2):150-157. doi:10.4314/ejhs.v23i2

55. Trieu PD, Mello-Thoms C, Peat JK, Do TD, Brennan PC. Risk factors of female breast cancer in Vietnam: a case-control study. Cancer Res Treat. 2017;49(4):990-1000. doi:10.4143/crt.2016.488 


\section{Publish your work in this journal}

The International Journal of Women's Health is an international, peerreviewed open-access journal publishing original research, reports, editorials, reviews and commentaries on all aspects of women's healthcare including gynecology, obstetrics, and breast cancer. The

manuscript management system is completely online and includes a very quick and fair peer-review system, which is all easy to use. Visit http://www.dovepress.com/testimonials.php to read real quotes from published authors. 